\title{
Recent advances in excavation, design and support methods: A case study of Mangdechhu project, Bhutan
}

\author{
AK Mishra, RK Chaudhary and P Punetha \\ Mangdechhu Hydro Power Authority \\ Trongsa, Bhutan \\ ppunetha@yahoo.com
}

\begin{abstract}
Construction of hydro power projects in the Himalayan region poses various problems which can have direct implication on the cost and time schedule of the projects. Varying geological conditions necessitate use of modern methodologies for ensuringstability and overall time bound completion of the project.The 720 MW Mangdechhu HE project being undertaken by the MHPA in the Himalayas in the northern parts of Bhutan, is one such project. Here the project authorities have addressed the adverse geological conditions by adopting various technologies for achieving scheduled completion of the project while ensuring stringent quality norms and minimal cost overrun.The Project has encountered adverse geological conditions duringexcavation of the various appurtenant structures. The stability of the structures has been studied in detail by the aid of numerical modeling, and support measures evaluated. Accordingly, best engineering techniques have been adopted to ensure long term safety of the structures.This paper exclusively deals with these recent rock engineering solutions such as pre-excavation grouting, diaphragm wall etc. for overcoming construction related problems while ensuring quality norms and also maintaining the construction schedule dates for commissioning of the project by March 2018.
\end{abstract}

Keywords-Engineering; Excavation; Construction; stability; structures; penstock; surge shaft

\section{I.INTRODUCTION}

The 720 MW Mangdecchu HE project is a run off the river project, located on the Mangdechhu River in central Bhutan. The project comprises a $112 \mathrm{~m}$ high Concrete Gravity Dam with four spillways, two $340 \mathrm{~m}$ long, $14 \mathrm{~m}$ wide $17 \mathrm{~m}$ high underground Desilting Chambers, a 13.5 $\mathrm{km}$ long, $6.5 \mathrm{~m}$ dia. Head Race Tunnel, an open to air, $152 \mathrm{~m}$ deep and $13.5 \mathrm{~m}$

Diameter surge shaft,two numbers pressure shafts of $3.5 \mathrm{~m}$ diameter and $1910 \mathrm{~m}$ length of stepped configuration between El. 1650 and $1014 \mathrm{~m}$ and finally bifurcating into four nos. of $2.5 \mathrm{~m}$ diameter circular penstocks, a $155 \mathrm{~m}$ long, $23 \mathrm{~m}$ wide, $41 \mathrm{~m}$ high underground power house cavern housing 4nos.Pelton turbines of $180 \mathrm{MW}$ each and a $1.33 \mathrm{~km}$ long Tail Race Tunnel. The project construction was initiated in the year 2012 and is now nearing completion with targeted generation expected in March 2018.

\section{LOCATION AND REGIONAL GEOLOGICAL SETTING:}

Geographically the project is spread in an area encompassing approx.. $2.5 \mathrm{sq} \mathrm{km}$, comprising a part of the Central Himalayas within rocks of both the Thimpu Gneissic Complex and the Cheka Formation which are both significant litho domains of Bhutan and cover wide regions of the country. The rock mass in the area is dominantly gneissic with interbedded biotite /muscovite schist's in the Thimpu Gneissic complex while quartzite's with interbedded schists are dominant in the Cheka formation. Foliation, the major discontinuity, is generally sub horizontal by virtue of which strong structural control is exercised in all underground excavations with the roof sections being prone to slabbing. This feature has thus been responsible for major tunneling problems particularly in reaches associated with high water table where water ingress resulted in creation of both continuous over-breaks and cavity formations. The Geological ground conditions were to some extent divergent from DPR level predictions which led to engineering problems in both surface and underground excavations, consequently so as to maintain and meet schedule and restrict escalation of project cost, Innovations in design, excavation and support methodologies had to be introduced in the construction of various engineering structures. The methods and practices thus adopted are briefly described below:

\section{CONCRETE DAM ABUTMENT AND FOUNDATION:}

To accommodate the $112 \mathrm{~m}$ high concrete dam in a narrow, confined gorge of 150 mwidth necessitated deep cutting of both abutments which led to creation of cutslopes which in certain sections had a depth of $192 \mathrm{~m}$. The design philosophy was to limit excavation in rock while resorting to removal of overburden and dress the slope for best stability. However variations in topography, presence of natural undercuts at bed level, excavation encroachments in higher level vegetation occasionally led to creation of slope stability problems. This aspect was further augmented by presence of certain adversely oriented discontinuity sets, having large strike persistence 
(sometimes of the order of $30 \mathrm{~m}$ ) which exercised control on the stability of the abutments.

These joints displayed openings upto $50 \mathrm{~cm}$ and were found to exist well within the confines of the abutment thus necessitating removal to depth. To study the collective effect of all these negative features and ensure stability of the abutments, NIRM was requested to carry out numerical modelling studies on a periodical basis. During this period the cut slopes were monitored rigorously by the aid of an instrumentation program, while the slopes were treated by the aid of $12 \mathrm{~m}$ deep consolidation grouting, $25 \mathrm{~m}$ deep tendons, rock bolts and shotcrete. The FOS of the rock slope sections were evaluated prior to treatment and subsequently Never the less some minor slope failures did take place both in the rock and overburden slopes in close vicinity to the concrete dam, due to incessant rainfall during monsoons

The overburden failures were treated by the aid ofwith installed support system and found to be well within the desired limits. Non frame stabilization method by the aid of $5 \mathrm{~m}$ long soil nails installed in a grid supplemented by wire

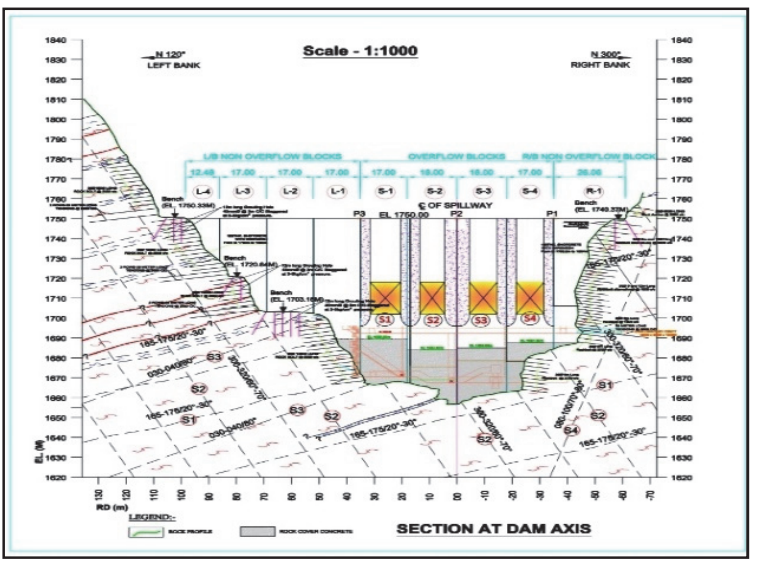

Fig.1. Geological section along axis of Concrete Gravity Dam depicting rock support

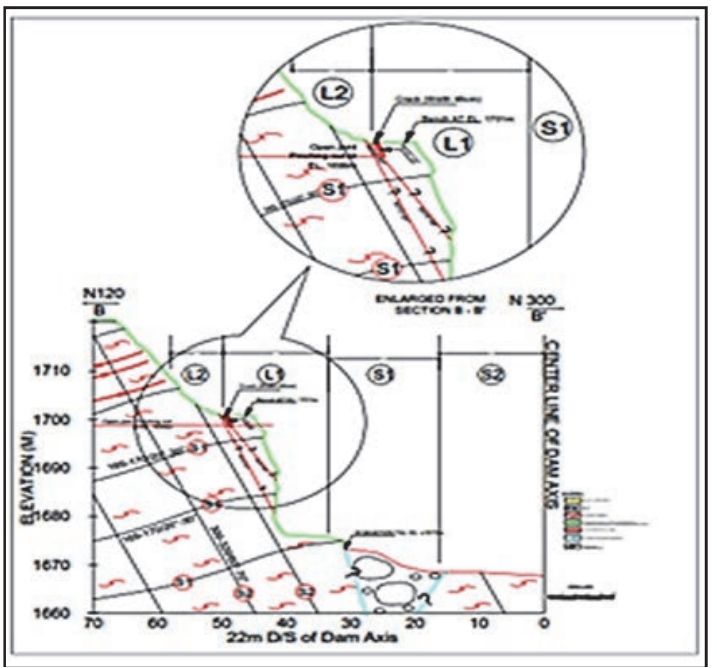

Fig.2. Cross section at Dam Axis showing Dam Blocks and depicting slump joints

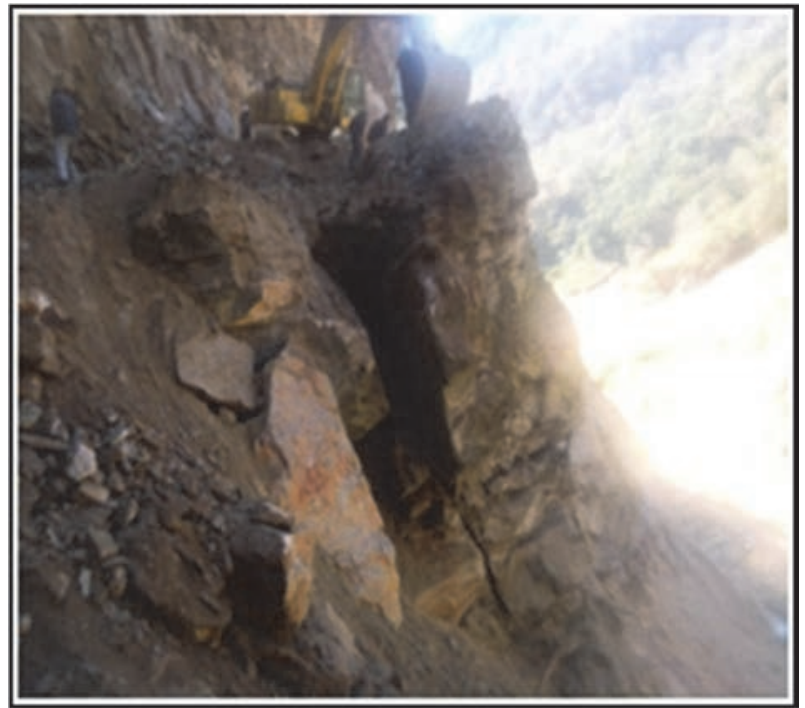

Fig.3. Dam excavation in progress depicting slump joints

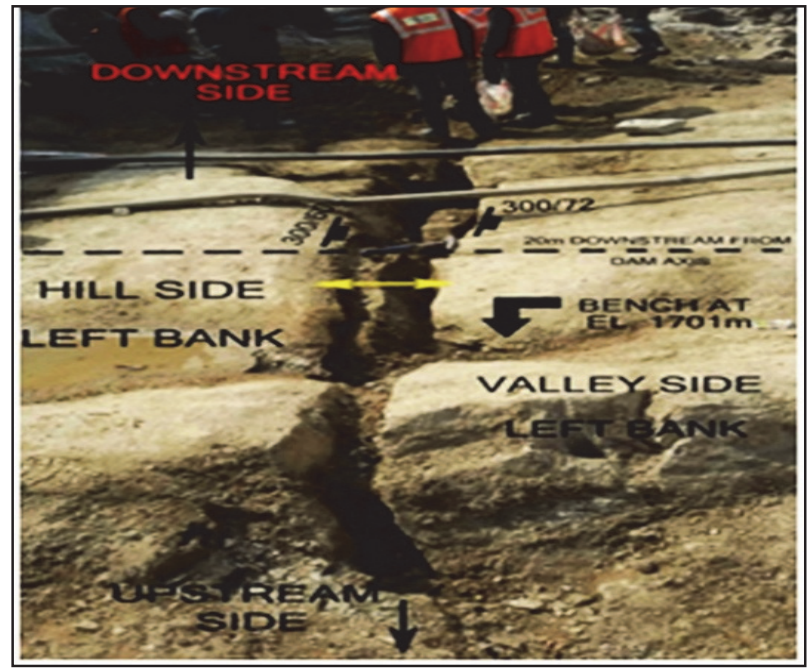

Fig.4. Plan view of open joints

mesh and jute matting.The non-frame method is an active support technique for stabilizing slide zones in both homogenous and heterogeneous medium and is contrastingly different from the passive support techniques such as concrete retaining walls and gabions presently being resorted to for dealing with potentially active slides. Non frame reinforces slopes by transporting resisting force from bedrock to topsoil being structured by a number of imbedded steel bars (soil nails) connected to each other by a triangular wire net.

\section{SURGE SHAFT:}

The $13.5 \mathrm{~m}$ dia., $152 \mathrm{~m}$ deep open to air surge shaft and its $72 \mathrm{~m}$ high open cut back slopes have been excavated invery poor to fair rockmass of the Cheka Formation comprising thinly foliated inter bedded sequence of biotite schist and quartzite. Deep seated weathering within the schist bands and fracturing of the quartzite had contributed to very poor tunneling conditions in the Surge 


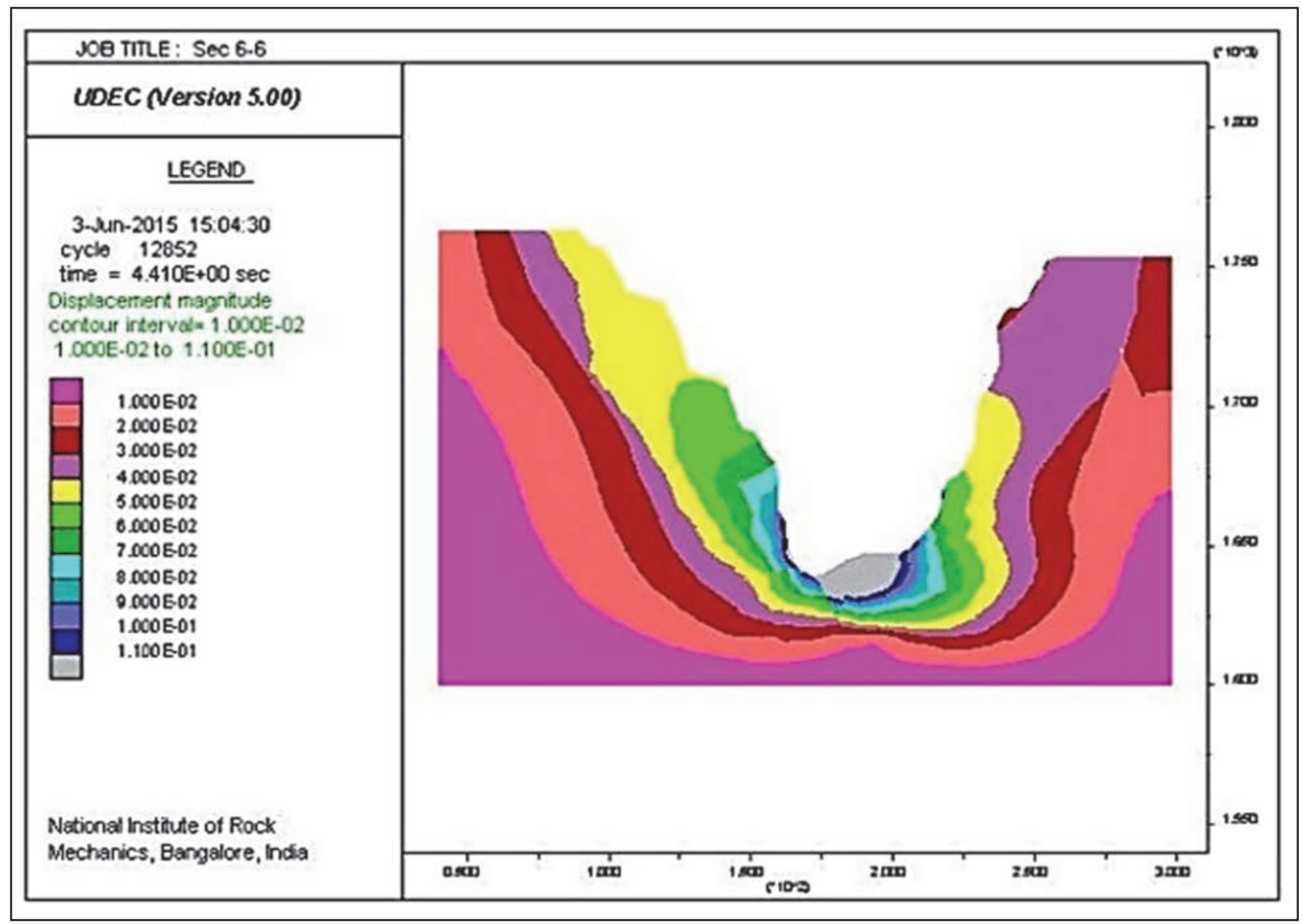

Fig.5. Typical displacement contours obtained from UDEC [1]

Shaft, Valve Chamber and the Penstock Erection Galleries, for which special excavation and support methodology had to be devised comprising pre and post excavation grouting, 9 to $12 \mathrm{~m}$ deep rock anchors, shotcrete and ISMB 250 steel ribsat $0.5 \mathrm{mspacing}$. In view of the greater schist component in the rock mass constituting the surge shaft, pre grouting around the periphery with OPC having a water cement ratio of $1: 1$ at significantly high pressures was required to achieve consolidation of the weathered medium followed by 9 to $12 \mathrm{~m}$ long rock anchors and shotcrete of $100 \mathrm{~mm}$ thickness. The excavated profile was supported by ISMB 250 steel rib sections at $0.5 \mathrm{~m}$ interval anchored to the rockmass by the aid of $36 \mathrm{~mm}$ dia., dowels of $3 \mathrm{~m}$ length. Simultaneously with the excavation peripheral grouting was taken up radially in the form of two concentric rings around a zone, $4 \mathrm{~m}$ and $7 \mathrm{~m}$ away from the periphery of the shaft to a depth of $100 \mathrm{~m}$.

Coring of the grouted rock mass was carried out and the engineering parameters tested at IIT Delhi, for ascertaining the efficacy of the grouting. Improvement in engineering parameters was noted as follows:Microscopic thin section studies revealed that all fractures and cracks in the specimens were filled with cement grout with good contact at the rock/ grout interface without voids. Thickness of grout fill ranged from $3 \mathrm{~mm}$ to $20 \mathrm{~cm}$.Increase in density (both dry and saturated) from 2.56 to $3.12 \mathrm{gm} \mathrm{/cc}$ indicating that grout fill had clearly improved the physical properties of rock.

The Brazilian strength values for Quartz Mica schist for both ungrouted and grouted samples were found to increase from $8.17 \mathrm{MPa}$ to $15.44 \mathrm{MPa}$ respectivelyindicating that the grout in fractures improved the tensile behavior of the rock mass. The shear factors i.e. cohesion and friction angle for grouted quartz mica schist specimens were found to be $5.373 \mathrm{KPa}$ and $40^{\circ}$ respectively indicating a marked improvement from the

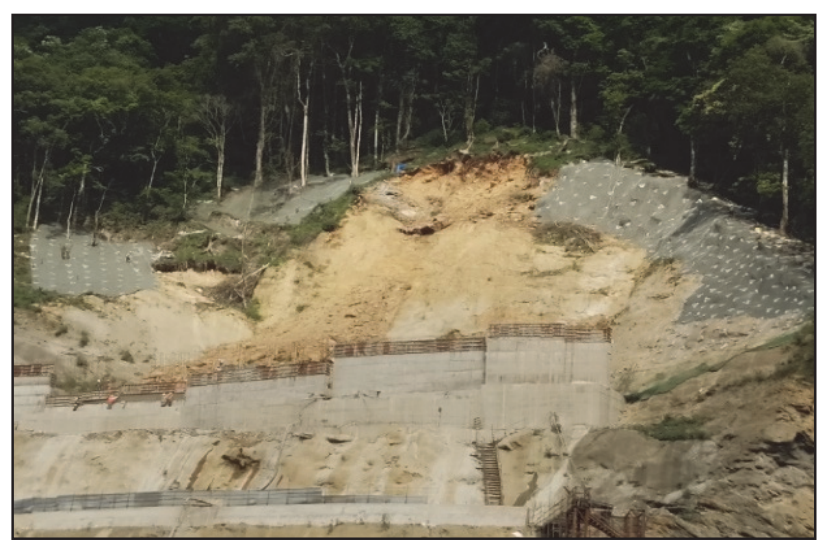

Fig.6. Non frame support work in progress left bank 


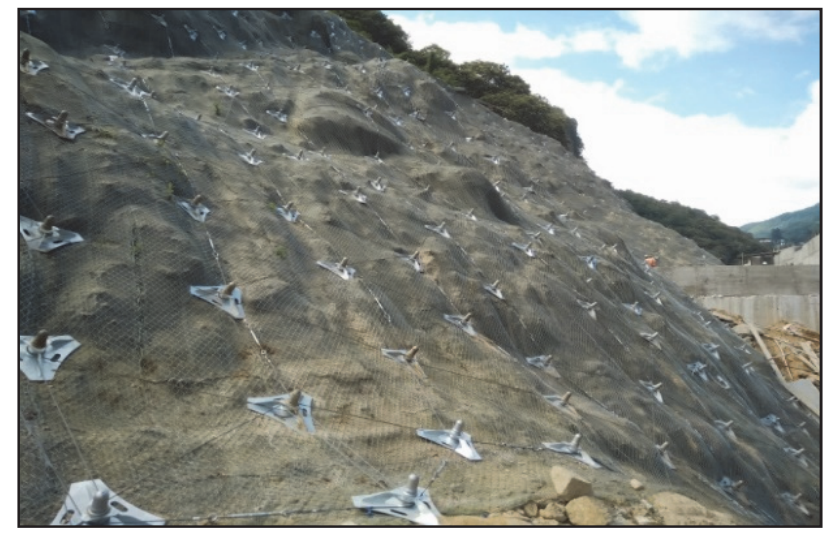

Fig.7. Supported Left Bank

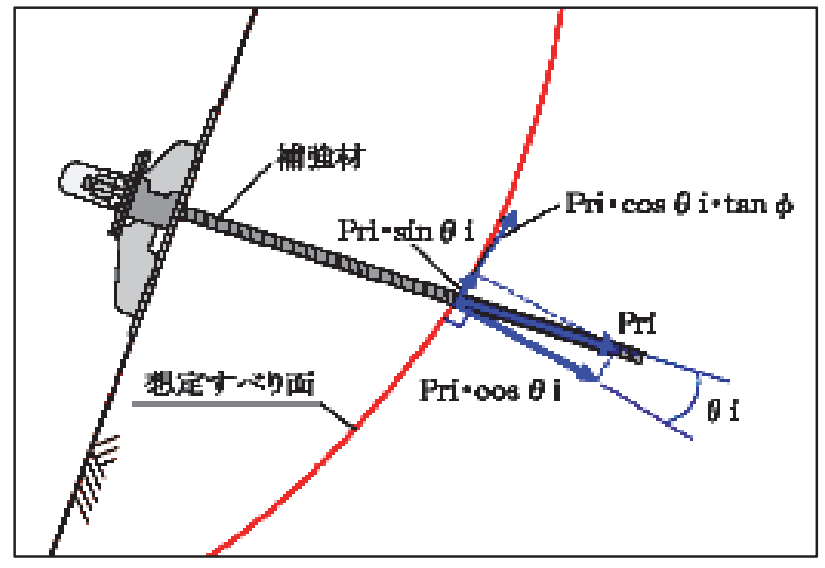

Fig. 8.Typical section depicting soil nail arrangement

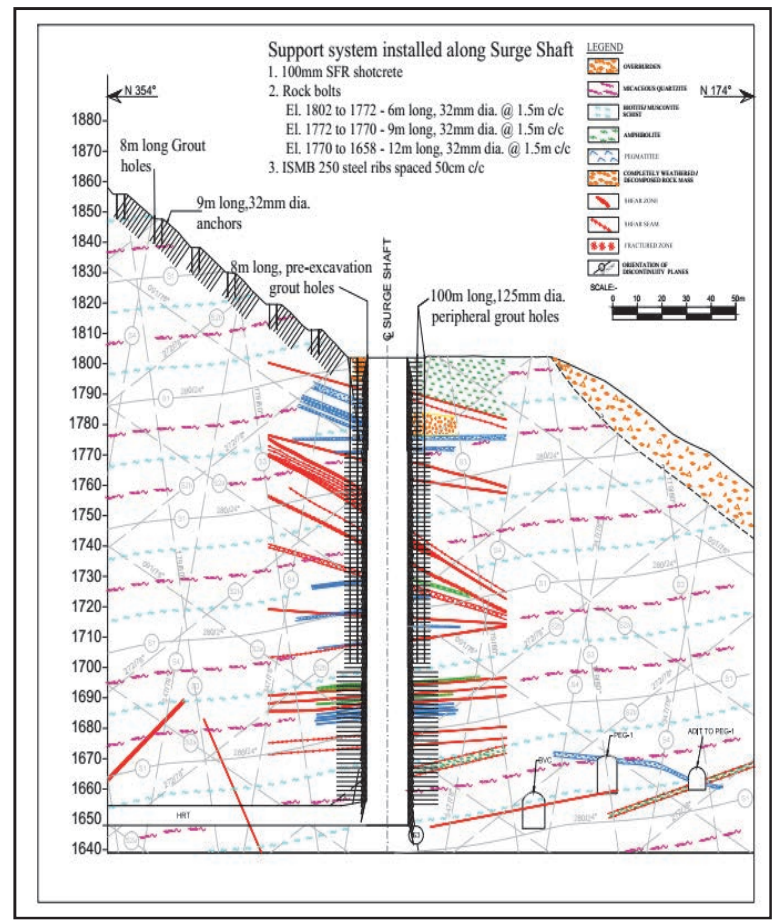

Fig.9. Geological L section of Surge Shaft showing rock support

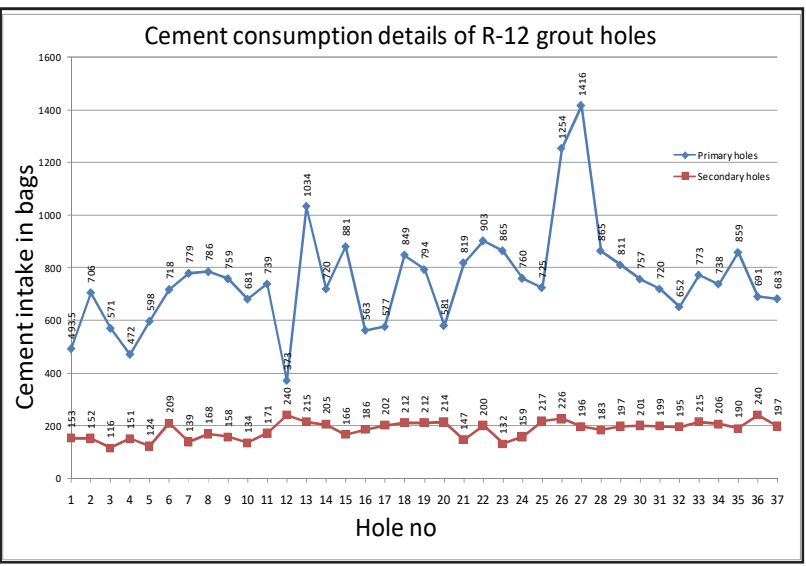

Fig.10. Grout takes for R-12 Peripheral Grouting (Bags)

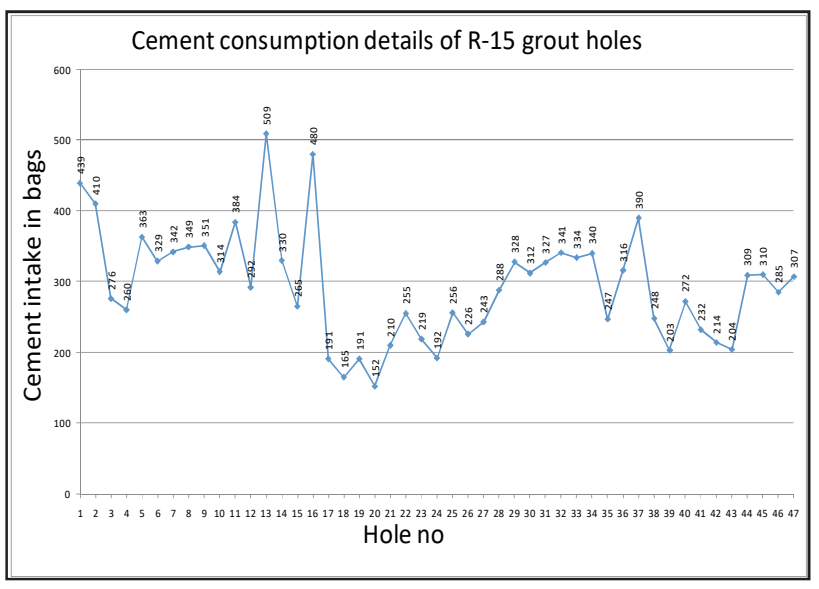

Fig.11. Grout takes for R-12 Peripheral Grouting (Intake/m) 


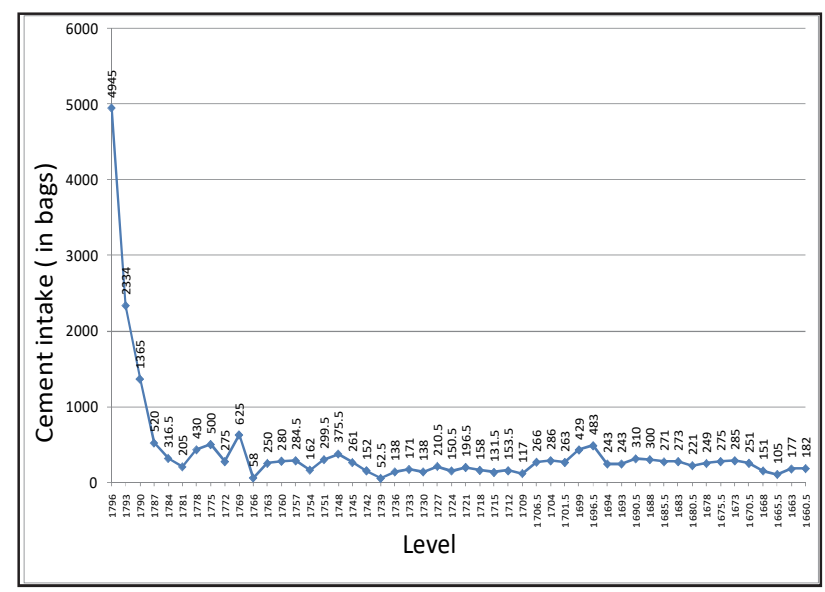

Fig.12. Grout takes for R-15 peripheral grouting (Bags)

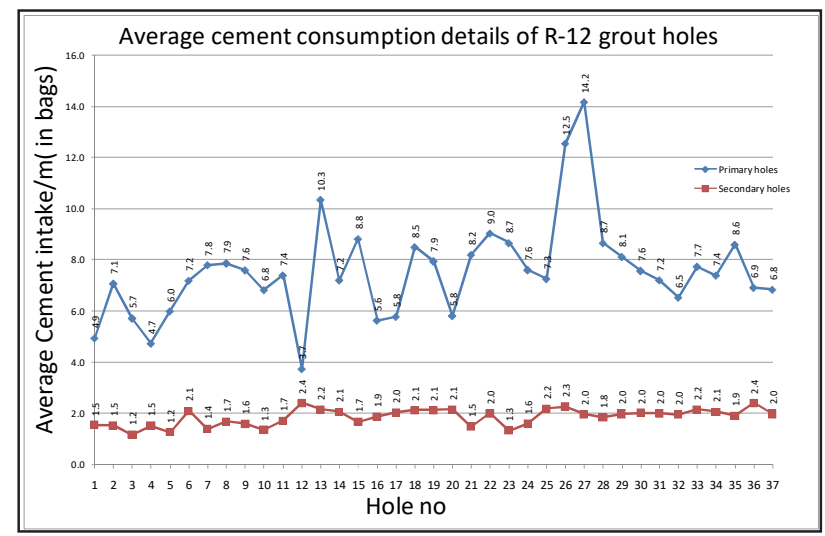

Fig.13. Grout takes for R-15 peripheral grouting (Intake $/ \mathrm{m}$ )

TABLE I ROCK TYPE AND ENGINEERING PARAMETERS

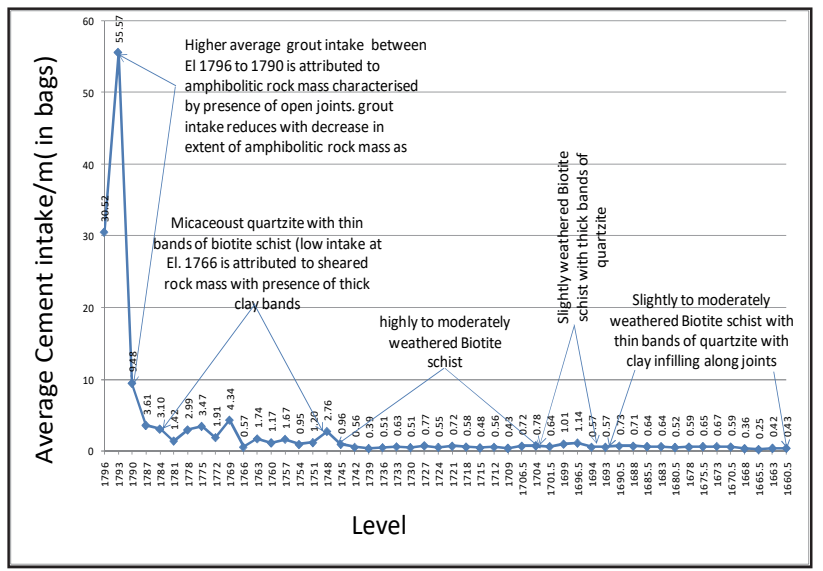

Fig.14. Grout takes for pre excavation grouting (Bags)

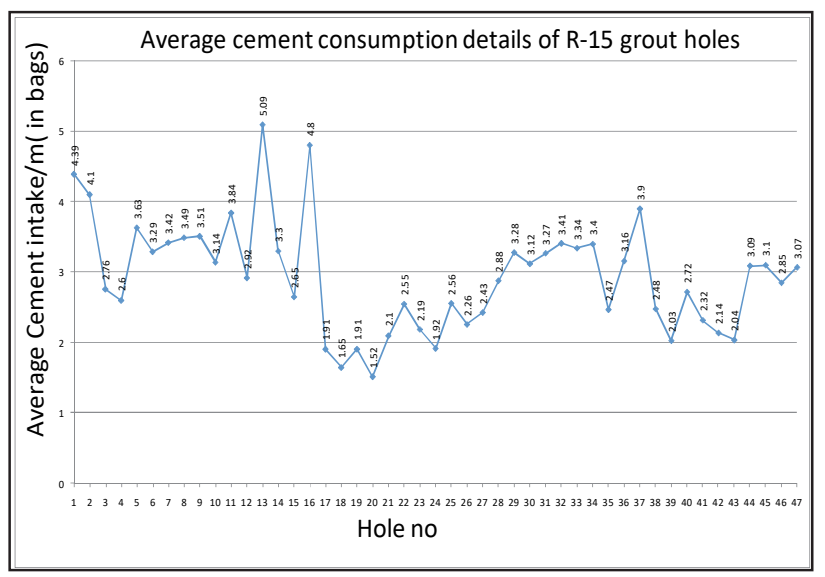

Fig.15. Grout takes for pre excavation grouting (Intake /m )-

\begin{tabular}{|c|c|c|c|c|l|}
\hline Rock type & $\begin{array}{c}\text { Engineering } \\
\text { parameters }\end{array}$ & Treated & Untreated & \% Increase & Remarks \\
\hline & $\begin{array}{c}\text { Tensile strength } \\
\text { (MPa) }\end{array}$ & 15.44 & 7.49 & 106.3 & \multicolumn{1}{|c|}{ Increase of $106 \%$} \\
\cline { 2 - 6 } & $\begin{array}{c}\text { Water content } \\
(\%)\end{array}$ & 0.35 & 0.40 & -14.0 & $\begin{array}{l}\text { Reduced by 14\% indicating filling of voids by grout, hence } \\
\text { reduction of available volume for accumulation of water }\end{array}$ \\
\cline { 2 - 6 } $\begin{array}{c}\text { Quartz } \\
\text { mica } \\
\text { schist }\end{array}$ & $\begin{array}{c}\text { Dry density } \\
\text { (g/cc) }\end{array}$ & 2.82 & 2.67 & 5.7 & $\begin{array}{l}\text { Increased by 6\% indicating void filling by grout and } \\
\text { consolidation }\end{array}$ \\
\cline { 2 - 6 } & $\begin{array}{c}\text { Saturated density } \\
\text { (g/cc) }\end{array}$ & 2.83 & 2.68 & 5.6 & $\begin{array}{l}\text { Increase in saturated density is attributed to increase in dry } \\
\text { density. }\end{array}$ \\
\hline $\begin{array}{c}\text { Cohesive strength } \\
\text { (KPa) }\end{array}$ & 5.37 & 0.00 & Increase & $\begin{array}{l}\text { Increase from 0 to 5.373 KPa, indicates increase in } \\
\text { cohesion after grouting which along open joints was zero } \\
\text { and is attributed to filling of void by grout. Increase in } \\
\text { cohesive strength from zero to 5.373 KPa after grouting } \\
\text { resulted in improving shear strength of the rock mass and } \\
\text { thus increasing stability of the structure with response to } \\
\text { shearing stresses }\end{array}$ \\
\cline { 2 - 6 } & $\begin{array}{c}\text { Angle of internal } \\
\text { friction (degree) }\end{array}$ & 40.36 & 33.38 & 20.9 & $\begin{array}{l}\text { Increase of 21\% has resulted in remarkable increase in } \\
\text { shear strength ensuring better stability of the structure with } \\
\text { respect to shearing stresses }\end{array}$ \\
\hline
\end{tabular}


earlier recorded observation of0 $\mathrm{KPa}$ along N080 $\mathrm{E}$. The Caverns are located on the left bank of Mangdechhu on the upstream of Yurmuchhu - Mangdechhu Confluence with a superincumbent rock cover of almost $200 \mathrm{~m}$. Both the caverns have been excavated in hard, strong to very strong quartzites of the Cheka Formation with intermediate biotite schist lenses and pegmatite veins.It was noted that the encountered geological conditions differed considerably from the DPR level studies wherein the cavern was assessed to generally be excavated in $77 \%$ class III (fair ) and $23 \%$ class II (good ) rock mass, while the encountered geological conditions suggested almost $85 \%$ class III (fair ) rock mass and $15 \%$ Class IV (i.e. poor ) rock mass.

During the excavation of central gullet and upstream and downstream slashing (EL: $1052.00 \mathrm{~m}$ to $1045.00 \mathrm{~m}$ ), $87 \%$ of total length was excavated in Fair (Class III) category of rock mass and $13 \%$ in Poor (Class IV)category of rock mass. During further benching of the Cavern i.e. from EL: $1045 \mathrm{~m}$ to $1021 \mathrm{~m}, 85 \%$ Class III (Fair) rock mass and $15 \%$ Class IV (Poor) rock mass has been encountered.

During the excavation of central gullet of Power House Cavern and Transformer Cavern, a $1.5 \mathrm{~m}$ thick/wide shear zone comprising of sheared and fractured rockmass (maximum width/thickness of fractured rock mass upto $8 \mathrm{~m}$ ) and attitude $\mathrm{N} 280^{\circ}-290^{\circ} / 15^{\circ}$ to $20^{\circ}$, was intercepted between RD $125 \mathrm{~m}$ to $155 \mathrm{~m}$ (between EL $1052 \mathrm{~m}$ to $1044 \mathrm{~m}$ ) and RD 70 to $90 \mathrm{~m}$ (EL: $1056.501048 .50 \mathrm{~m}$ ) respectively. The disposition of the shear zone was such that it was expected to intersect the crane beam columns of both the Caverns at varying elevations and to intersect the entire length of the Caverns while also bisecting the intermediate rock pillars.

A. The presence of shear/fractured zone in various reaches of both the Powerhouse and Transformer Caverns was expected to have the following implications during excavation:Powerhouse:

- Settlements in the crane beam columns

- Instability of the downstream crown area above the service bay corresponding to levels at EL: $+1046 \mathrm{~m}$.

- Instability of the rock column between the two caverns corresponding to the area above \& between the Bus ducts.

B. Transformer cavern:

- Instability of the crown from RD $70 \mathrm{~m}$ onwards, particularly at the junction with the fractured pegmatite band encountered between RD 75-135m.

- Settlement in the crane beam columns, particularly along the upstream wall. Instability between the inclined Bus Duct openings in the upstream wall.

In view of the presence of the shear zone and its disposition affecting both Caverns coupled with formation of cavities, it was collectively decided by MHPA and the consultant to reassess the stability of both Caverns while also revalidating the rock support and excavation methodology thereof. The following 2 options were thoroughly studied/ investigated viz;

I)Shifting of the Power House and Transformer Caverns: By shifting about 40m laterally towards Valley side whereby the Crown of the Caverns could be relatively free from the effect of the shear zones.

II)Non-shifting of the Power House and Transformer Caverns: The longitudinal shifting as proposed at Serial No. (I) as above, would result in the Shear/Fractured Zone intersecting the Unit-IV Turbine Foundation and such an alternative may attract subsidence in future during the operation and maintenance of the Power House. Therefore, it is felt prudent to treat the Shear/Fractured Zone in-situ, instead shifting the Power House and Transformer Caverns by $40 \mathrm{~m}$. The Technical discussions hovered around the likely deformations in crown and also in vertical walls incase project goes for non-shifting i.e. proposal at Serial No. (II). To develop the confidence, it was decided in the Technical Co-ordination Committee (TCC) meeting to go for 3D Numerical Modelling through NIRM, Bengaluru.

Considering the presence of weak rockmass associated with the shear zone and to effectively deal with frequent loose fall from these zones it was decided to provide steel ribs support (ISMB $350 @ 0.5 \mathrm{~m} \mathrm{C} / \mathrm{C}$ ) between RD 0 to 35 and RD 100 to 155 at the Power House cavern and between RD 0 to 20 and RD 60 to 120m (ISMB $350 @ 1 \mathrm{~m}$ $\mathrm{C} / \mathrm{C}$ ) in the Transformer Cavern. Accordingly, NIRM was approached for carrying out 3DEC modeling studies of the underground Caverns, while the work of redesigning the support system based on the stability studies, were taken up progressively with the ongoing excavation. The actual deformation observed and recorded at site during excavation was closely monitored and compared with predicted/anticipated displacements in the 3DEC numerical modeling studies. The maximum deformation as anticipated at Crown of Machine Hall was $27.8 \mathrm{~mm}$ whereas maximum deformation observed at site was only $13 \mathrm{~mm}$ (as on 30.06.15). Similarly the anticipated deformation at $\mathrm{U} / \mathrm{s}$ and $\mathrm{D} / \mathrm{s}$ wall of Machine Hall was assessed as $78.69 \mathrm{~mm}$ and $61.49 \mathrm{~mm}$ whereas maximum deformation observed was $13.6 \mathrm{~mm}$ and $39.7 \mathrm{~mm}$ respectively (as on 30.06.15).

The 3DEC modelling studies in brief suggested that:

The FOS reduced marginally for areas in the proximity of the excavated Caverns however the rock mass in the fractured zones associating with the shear zone, in particular for the bus duct pillars was found to be very low i.e. less than 1 which could be attributed to the low strength of the fractured rock mass and also to the tensile stresses acting in these areas.

The application of scooping out 1.5 to $3 \mathrm{~m}$ of fractured zone and back filling by concrete (M30), around the excavated Caverns significantly improved the FOS. The above remedial measures were found to be quite successful in eliminating failure zones at the face of the Caverns. Similarly $12 \mathrm{~m}$ long, $32 \mathrm{~mm}$ dia. rock bolts were installed at the crown portion of both Power House and Transformer Caverns at a spacing of $3 \mathrm{~m}$ center to center. Shotcrete thickness was also increased from $200 \mathrm{~mm}$ to $250 \mathrm{~mm}$ on the roof and wall of PH Cavern and TH Cavern.Significant areas in the rock pillar between Power House Cavern and Transformer Cavern indicated failure in the initial studies. 
The requirement for review of support system in the Bus Ducts and application of suitable remedial measures were taken up accordingly. Subsequently stitching of the rock pillar between the Bus Ducts by aid of $36 \mathrm{~mm}$ dia., $17 \mathrm{~m}$ long rock bolts at the spacing of $1.5 \mathrm{~m} \mathrm{c} / \mathrm{c}$ was proposed and implemented at site. After stitching the rock pillars between individual Bus Ducts, the displacement was observed to have reduced considerably thereby improving the stability.

The rib sections provided at different locations at both the Caverns were found to be effective in distribution of the movements/ loads in roof thus improving the stability of the rockmass around the Caverns. The report also concluded that in the presence of ribs, the displacement in the wall also reduced as the ribs were found to control load transfer on the haunch.

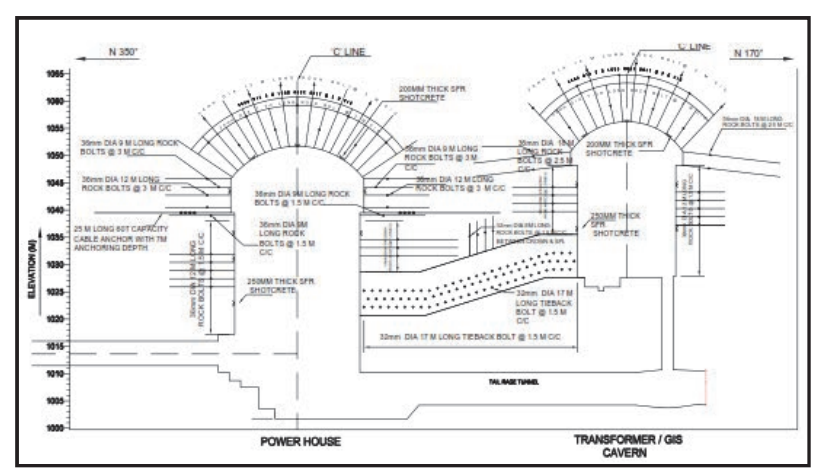

Fig.16. Cross Section of Power House and Transformer Caverns showing Details of rock support system

Additional geo-technical instruments (MPBX, up to $20 \mathrm{~m}$ depth and Load cell with 100 ton capacity) were also installed for monitoring deep seated deformation as suggested in the 3DEC report.

The cross section of Power House and Transformer Caverns showing details of rock support system installed at site is given below:

\section{Shear Zone treatment:}

The shear/fractured zone was treated progressively during course of excavation of both the Caverns. The shear/fractured rock mass wherever exposed was scooped out upto a maximum depth of 1.5 to $3 \mathrm{~m}$ and filled with rich concrete of greater strength (M30). Consolidation grouting (stage grouting of $3 \mathrm{~m}$ sections) was also carried out upto the depth of $20 \mathrm{~m}$ using micro fine/ultrafine cement with grout mix 5:1 to $0.8: 1$ (ratio by weight of water and cement) and maximum pressure upto $30 \mathrm{~kg} / \mathrm{cm} 2$. In order to control grout leakages in fracture rock mass inflatable packers were also used.

\section{Consolidation and contact grouting:}

Power House Cavern: The Machine Hall Cavern was strengthened by aid of consolidation grouting upto the depth of $6 \mathrm{~m}$. $45 \mathrm{~mm}$ dia., grout holes were drilled at a spacing of $1.5 \mathrm{~m} \mathrm{c} / \mathrm{c}$ in a staggered manner and grouting with micro fine cement having 2:1 to $1: 1$ water cement ratio was carried out. Similarly consolidation of Transformer Hall Cavern medium was carried out with the aid of $6 \mathrm{~m}$ depth grout holes.Maximum pressure of $14 \mathrm{~kg} / \mathrm{cm} 2$ was applied during consolidation grouting.

The actual deformation observed and recorded at site during excavation was closely monitored and compared with predicted/anticipated displacements in the 3DEC numerical modeling studies. The maximum deformation as anticipated at Crown of Machine Hall was $27.8 \mathrm{~mm}$ whereas maximum deformation observed at site was only $13 \mathrm{~mm}$ (as on 30.06.15). Similarly the anticipated deformation at $\mathrm{U} / \mathrm{s}$ and $\mathrm{D} / \mathrm{s}$ wall of Machine Hall was assessed as $78.69 \mathrm{~mm}$ and $61.49 \mathrm{~mm}$ whereas maximum deformation observed was $13.6 \mathrm{~mm}$ and $39.7 \mathrm{~mm}$ respectively (as on 30.06.15). The graphical presentation of instrumentation for monitoring the rate of deformation vis-à-vis excavation sequences comparing anticipated deformation and actual deformation observed at site during course of excavation of both the Caverns has been detailed in the figures provided below.

\section{POTHEAD YARD}

The 160m long, 42m wide Pothead Yard has been accommodated about $40 \mathrm{~m}$ downstream of the MAT portal, at an elevation of $1083 \mathrm{~m}$ at the base of the hill constituting the left bank of the Mangdechhu. The proposed Pothead yard is aligned in NNW - SSE direction, to facilitate creation of a sufficient wide bench at this location, the back slopes of the structure have been dressed to a height of $120 \mathrm{~m}$ i.e. from EL $1205 \mathrm{~m}$ at top to El $1083 \mathrm{~m}$ at the base by the aid of excavation of 8 nos. $15 \mathrm{~m}$ height benches of width $3 \mathrm{~m}$ ina slope whose gradient varies from $37^{\circ}$ to $53^{\circ}$ i.e. from 1:1.25 between El 1203 and El 1123 to 1:2 between El 1123 and El 1083m respectively, the average slope gradient being $40^{\circ}$. The typical slope geometry is depicted in a cross section at RD $10 \mathrm{~m}$ as given below:

The Pothead Yard is aligned almost parallel to the strike of the bed rock. The bed rock generally dips towards valley with moderate to gentle dips $\left(22^{\circ}\right.$ to $\left.40^{\circ}\right)$. Such exposed foliation dip surfaces are visible along the presently excavated benches and approach road. The parallelism between strike of the foliation and cut slopes

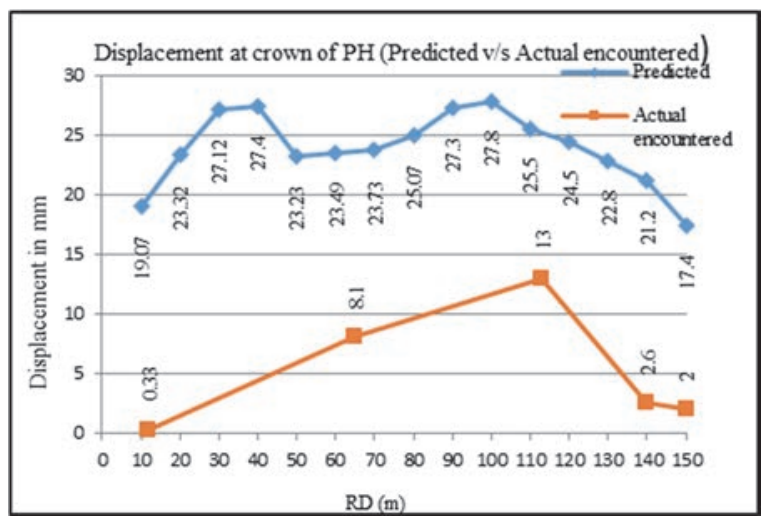

Fig. 17. Graphical presentation of actual $\mathrm{v} / \mathrm{s}$ predicted deformation at Crown of PH Cavern. 


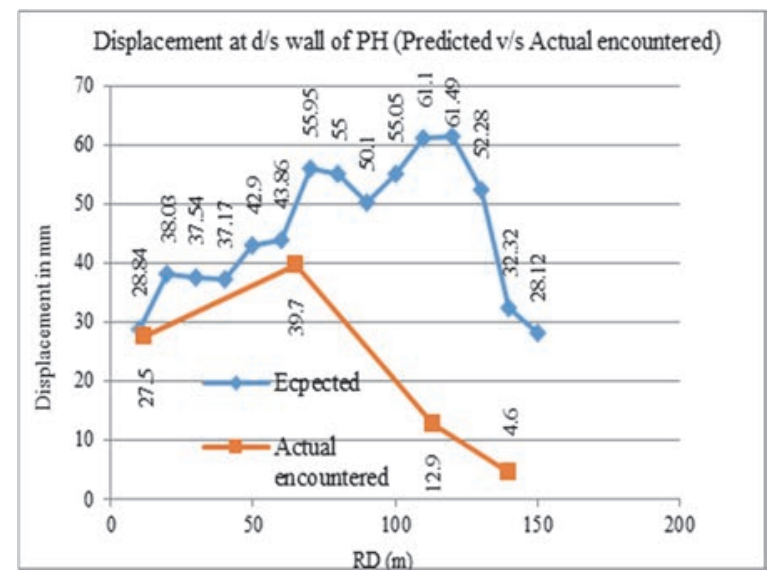

Fig.18. Graphical presentation of actual $\mathrm{v} / \mathrm{s}$ predicted deformation at $\mathrm{d} / \mathrm{s}$ wall of PH Cavern.

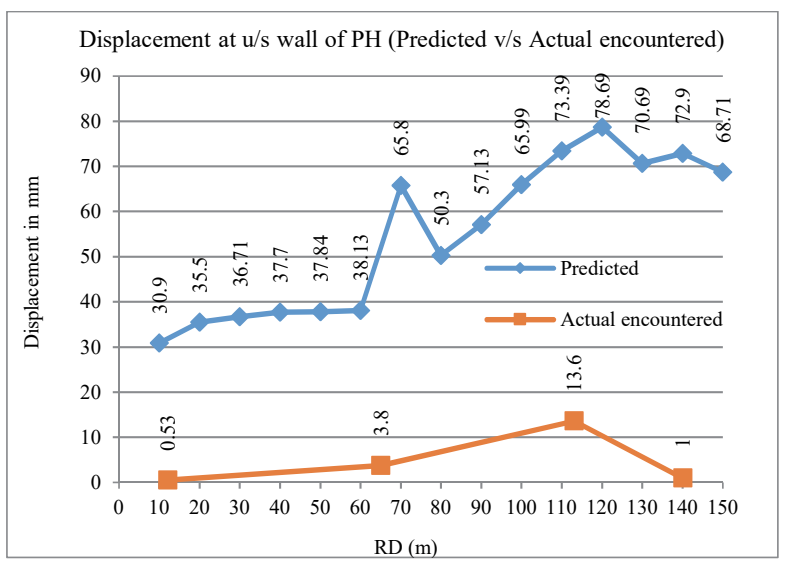

Fig.19.Graphical presentation of actual $\mathrm{v} / \mathrm{s}$ predicted deformation at $\mathrm{u} / \mathrm{s}$ wall of PH Cavern.

along with open character of the discontinuities was expected to induce failure along the foliation planes (planar failure) thus resulting in instability of the rock cut slopes. To ensure the stability of the cut slopes, extensive preand post excavation grouting both in the berms and the slope was carried out to fill the open discontinuities planes androck anchors of 7.5 to $9 \mathrm{~m}$ length $36 \mathrm{~mm}$ diameter were provided between El 1205 to $1138 \mathrm{~m}$ while $12 \mathrm{~m}$ length anchors were provided below EL. 1138. The cut slopes were covered in shotcrete of thickness of $150 \mathrm{~mm}$ with welded wire mesh and the excavation monitored by the aid of $10 \mathrm{~m}$ to $20 \mathrm{~m}$ depth multipoint bore hole extensometers and load cells. The stability of the cut slopes was also assessed by the aid of numerical modeling studies carried out by NIRM under dynamic conditions to assess the planned support system and suggest recommendations if any. The stability analysis was carried out along five sections using Discreet Element Numerical Model (UDEC) which is a two dimensional numerical program based on the distinct element method for discontinuum modeling. The factor of safety analyzed along five sections is tabulated below.

The predicted displacements obtained along five sections by numerical modeling were as follows:

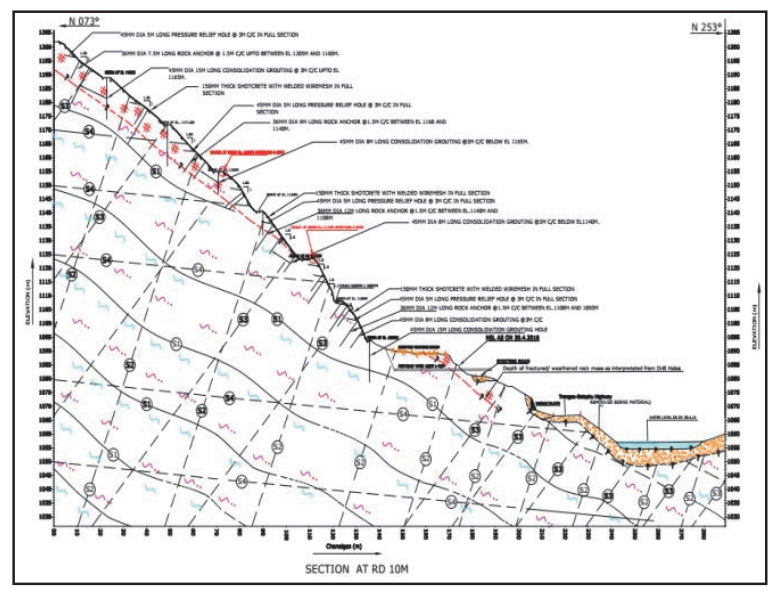

Fig.20. Geological Cross Section of Pothead Yard at RD 10m

Section AA': A maximum displacement of $90 \mathrm{~mm}$ was observed at El. $1078 \mathrm{~m}$ i.e. at the bottom elevation of the pothead yard. The bench slopes at El. 1099 to 1205 experienced displacement in the range of $70-80 \mathrm{~mm}$ at the top surface layer.

\section{TABLE II: FOS ALONG DIFFERENT SECTIONS}

\begin{tabular}{|c|c|}
\hline Location & FOS value \\
\hline Section AA' & 1.41 \\
\hline Section BB' & 1.83 \\
\hline Section CC' & 2.61 \\
\hline Section DD' & 2.78 \\
\hline Section EE' & 1.39 \\
\hline
\end{tabular}

Section BB': A maximum displacement of $90 \mathrm{~mm}$ was observed at El. 1078. The bench slopes between El. 1091 to 1139 experienced displacement in the range of 70$80 \mathrm{~mm}$, while the bench slopes between El. 1139 to El.1160 experienced displacement in the range of $60-70 \mathrm{~mm}$.

Section CC': A maximum displacement of $45 \mathrm{~mm}$ was observed at El.1134m, while the bench slopes between El. 1078 and 1134 experienced displacement in the range of $30-40 \mathrm{~mm}$. Section EE": The modeling results revealed the maximum displacement of $70 \mathrm{~mm}$ at El. $1103 \mathrm{~m}$, while Section DD": A maximum displacement of 25 to $30 \mathrm{~mm}$ was observed along the entire slope face between El.1078 to El. $1113 \mathrm{~m}$.

The bench slopes between El. 1103 and 1205 experienced displacement in the range of $50-60 \mathrm{~mm}$. Typical graphical representations of displacements and load measured at various Chainages and levelsby aid of MPBX and load cells are given below Meanwhile, during Oct 2015 some hair line cracks were observed in the shotcrete covering the berms and interconnecting slope faces between El 1108 to $1158 \mathrm{~m}$, mainly concentrated towards downstream of RD $110 \mathrm{~m}$ where weaker rockmass prevailed and natural slope gradients were gentler. 


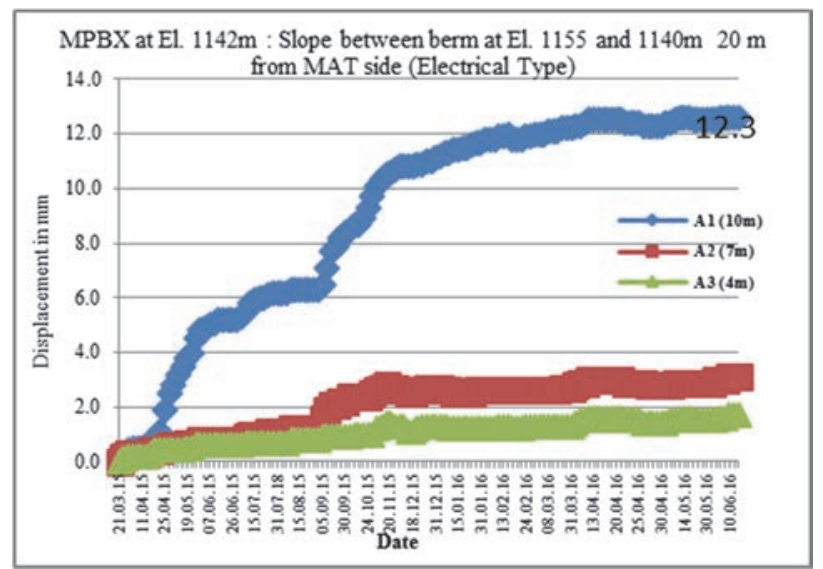

Fig.21.Graphical presentation of deformation at El.1142m

The appearance of these cracks raised apprehension of settlements in the weaker rock sections towards downstream and which called for immediate revalidation of support measures. Meanwhile upon the excavation reaching below $1090 \mathrm{~m}$, an approximately $50 \mathrm{~cm}$ to $1 \mathrm{~m}$ wide shear plane was encountered with dip towards downstream, as this feature could have repercussions on the stability issue, it was considered prudent to introduce $25 \mathrm{~m}$ long cable anchors as an additional measure to provide support to the toe of the excavation between El $1093 \mathrm{~m}$ and $1140 \mathrm{~m}$. In addition secondary and tertiary grout holes along the berms were also introduced for better consolidation of the rock mass.

The efficacy of the grouting is displayed in the photos below. Pre and post grouting water pressure tests carried out in $3 \mathrm{~m}$ stages, during secondary stage grouting of cable anchor drill holes, confirmed the elimination of voids and consolidation of rock mass as is evident by the values displayed in the Table III.

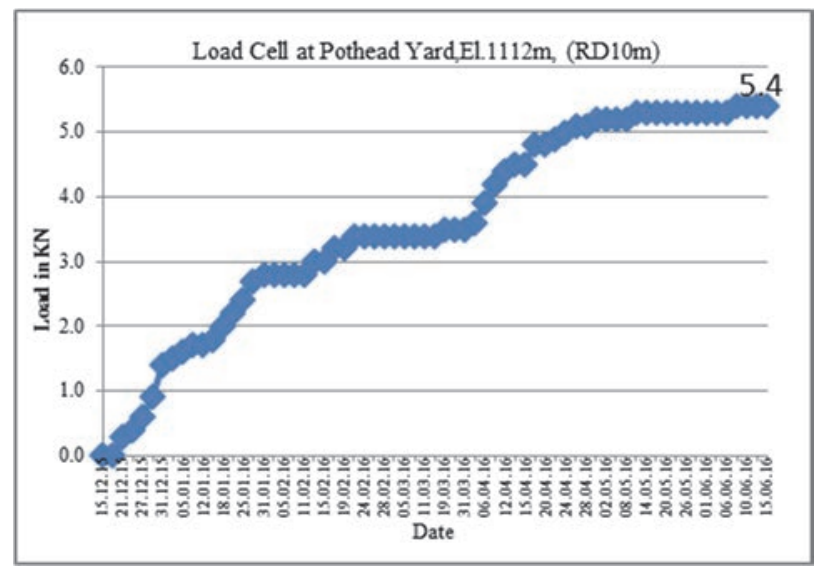

Fig.22.Graphical presentation of Load at El.1112m

From the above results inference could be drawn that the support measures resorted to were adequate for ensuring stabilization of the structure, which was further reinforced by the results of the stability analysis carried out by NIRM

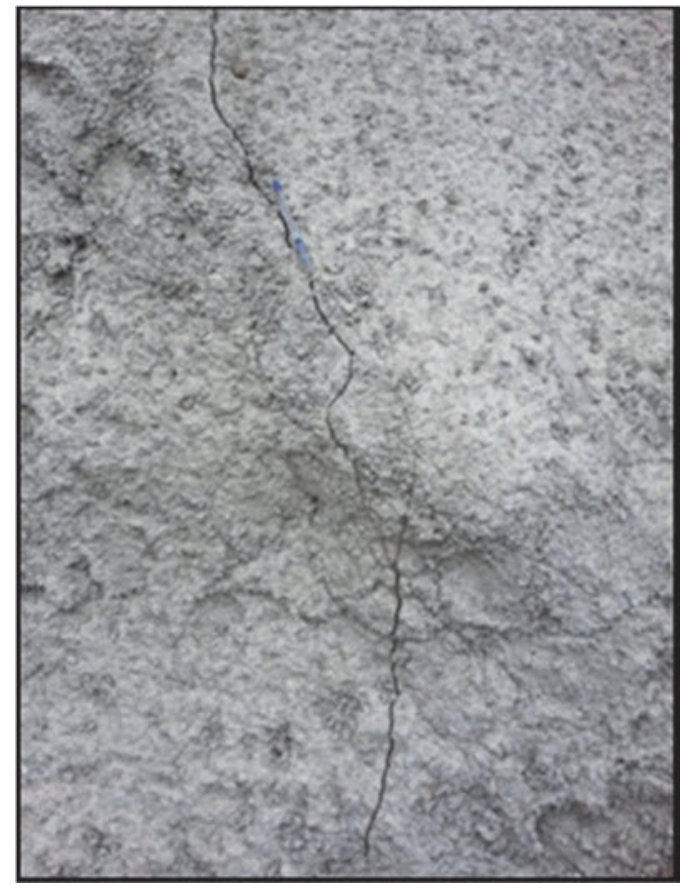

Fig.23. Showing Cracks in Shotcrete of Pothead yard

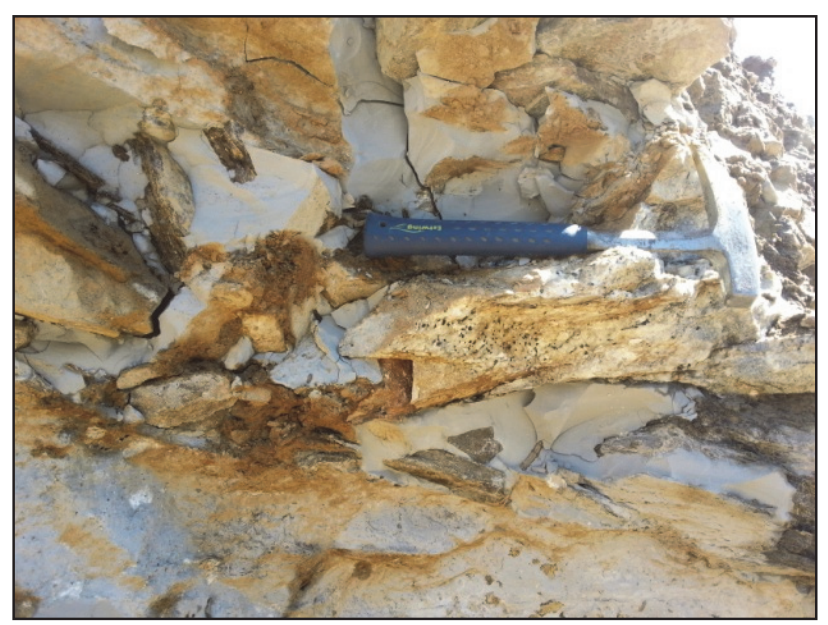

Fig.24. Grout imprints in excavated sections of pothead yard

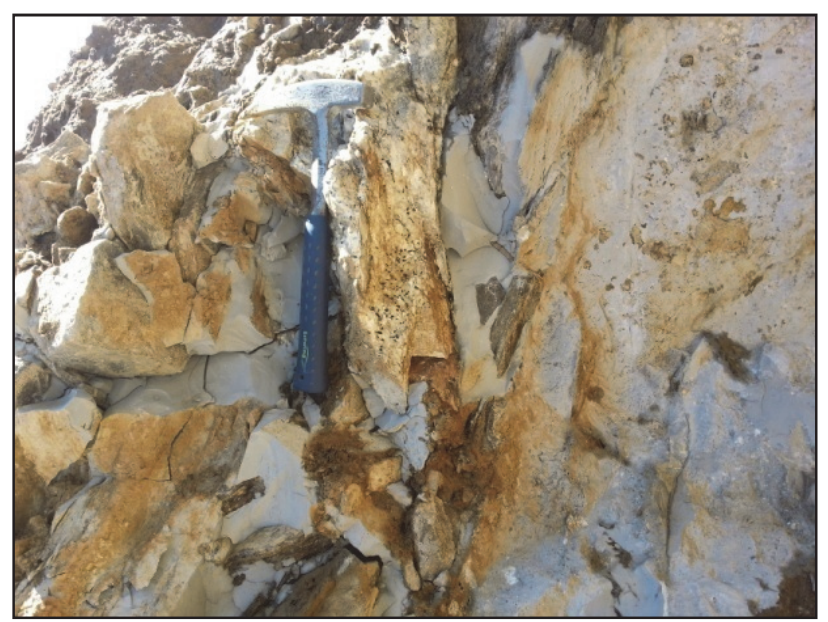

Fig.25. Grout imprints in excavated sections of pothead yard 
TABLE III. SHOWING WATER PERMEABILITY TEST RESUltS FOR CABLE ANCHOR INSTALLATION

\begin{tabular}{|c|c|c|c|c|c|c|c|c|c|c|c|c|}
\hline \multicolumn{13}{|c|}{ Water Permeability Test at Pothead Yard Cut slope for installation of Cable Anchor } \\
\hline RD (m) & 55 & 60 & 65 & 70 & 75 & 80 & 85 & 90 & 95 & 100 & 105 & 110 \\
\hline \multicolumn{13}{|c|}{ Depth(m) } \\
\hline $0-3$ & $>100$ & $>100$ & $>100$ & $>100$ & $>100$ & $>100$ & $>100$ & $>100$ & $>100$ & $>100 / 2.5^{*}$ & $>100$ & $>100$ \\
\hline $3-6$ & & & & & & 1.7 & 0.4 & 0.3 & 6 & $62.8 / 12.9^{*}$ & 120 & 17.2 \\
\hline $6-9$ & & & & & & 2.2 & 1.6 & 40.1 & 45.5 & $81.6 / 0.4^{*}$ & 26.3 & 17.74 \\
\hline $9-12$ & & & & & & & 0.4 & 8.5 & 4.4 & 1 & 7.97 & 0.81 \\
\hline $12-15$ & & & & & & & & & 0.3 & & & \\
\hline
\end{tabular}

* Post grouting Lugeon values

\section{VII.CONCLUSION:}

Successful completion of Excavation in Underground Machine Hall Cavern and also of Transformer Cavern, inspite intersecting the shear zones in the walls of both caverns, is attributable to numerical modelling analysis coupled with the rigorous instrumentation during excavation phase of MangdechhuProject. Similar to above, the deep excavations carried out in the Dam Abutments/Surge Shaft Back Slope along with the excavation in the Surge Shaft itself/deep open cut excavation in Pothead Yard are also contributing in the success of excavation phase in Mangdechhu Project. MHPA was cautious right from the beginning regarding analysis/instrumentation during theexcavation of caverns/deep slopes and preferred 3D numerical

modelling along with instrumentation. Hydro project structures are very sensitive to failures of slopes/caving in the Underground excavations and therefore, it would always be advisable to go for Numerical analysis with carefully selecting the process using the specific software especially $3 \mathrm{DEC}$ and FLAC 3D. Simulation of the ground conditions i.e. the rock joints / properties etc. are required to be incorporated to predict the behaviour of the Stress Contours which is to be again to be verified through the instrumentation. Validation of prediction and comparison of results i.e. numerical analysis versus actual behaviour is the key for success.

\section{REFERENCES}

[1] "Slope stability study at dam abutments and pothead yard locations," Technical Report by NIRM, 2015. 